\title{
Author Notes Provided by Corresponding Authors
}

\author{
Elizabeth A. Cudney
}

Dr. Elizabeth A. Cudney is an associate professor in the Engineering Management and Systems Engineering Department at Missouri University of Science and Technology. She received her B.S. in Industrial Engineering from North Carolina State University, Master of Engineering in Mechanical Engineering and Master of Business Administration from the University of Hartford, and her doctorate in Engineering Management from the University of Missouri - Rolla. In 2014, Dr. Cudney was elected as an ASEM Fellow. In 2013, Dr. Cudney was elected as an ASQ Fellow. In 2010, Dr. Cudney was inducted into the International Academy for Quality. She received the 2008 ASQ A.V. Feigenbaum Medal and the 2006 SME Outstanding Young Manufacturing Engineering Award. She has published six books and over 55 journal papers. She is an ASQ Certified Quality Engineer, Manager of Quality/Operational Excellence, and Certified Six Sigma Black Belt. She is a member of the ASEE, ASEM, ASQ, IISE, and the Japan Quality Engineering Society (JQES).

Correspondence concerning this article should be addressed to Elizabeth A. Cudney, Department of Engineering Management and Systems Engineering, Missouri University of Science and Technology, Rolla, MO 65409, USA. Email: cudney@mst.edu

\section{Fei Dai}

Fei Dai is an assistant professor at the Department of Civil and Environmental Engineering, College of Engineering and Mineral Resources, West Virginia University. His research interests and areas include construction engineering and construction management.

Correspondence concerning this article should be addressed to Fei Dai, 635 Engineering Sciences Building, 395 Evansdale Drive, Morgantown, WV 26506-6103, USA. Email: fei.dai@mail.wvu.edu

\section{Geert Letens}

Geert Letens is research fellow of Vlerick Business School and a Lieutenant Colonel of the department of economics, management and leadership at the Royal Military Academy, Belgium. He received a M.S. degree in telecommunications engineering from the Royal Military Academy in Brussels, a M.S. degree in mechatronics from KULeuven, and a M.S. degree in total quality management from Hasselt University. He holds a Ph.D. in applied economics from Ghent University and a Ph.D. in social and military sciences from the Royal Military Academy. As the CEO of Tchi-innovation, he has provided training and consulting services for more than 15 years to various fortune global 500 companies. His research interests include organization development and change, performance management, and lean product development. Geert was the 2012 president of the society for engineering and management systems of the Institute of Industrial and Systems Engineers (IISE) and IISE's Associate VP Europe from 2013 to 2015. He is certified as a Professional Engineering Manager (PEM). Dr. Letens is a fellow of the American Society for Engineering Management (ASEM) and currently serves as the 2015-2016 president of ASEM.

Correspondence concerning this article should be addressed to Geert Letens, Departmenet of Economics, Management and Leadership, Royal Military Academy, Av. De la Renaissance B-1000, Brussels, Belgium. Email: geertletens@yahoo.com 


\section{Tony Marjoram}

Dr. Tony Marjoram, FIEAust, CPEng, is a visiting professor at the UNESCO Centre for Problem Based Learning in Engineering Science and Sustainability at Aalborg University, Denmark, a world leader in Problem-Based Learning. He has a background in mechanical engineering, engineering education, science and engineering policy, planning and management, international and humanitarian development. He worked at and is an Honorary Fellow at Melbourne University and the Manchester Institute of Innovation Research, was a Development Fellow at the University of the South Pacific, and has published numerous papers, books, articles and reports. He worked at UNESCO for 18 years and was responsible for the UNESCO Engineering Programme from 2001 to 2011. His achievements include production of the UNESCO Report "Engineering: Issues, Challenges and Opportunities for Development" - the first international report on engineering and development, and the conception and management of the award-winning Daimler-UNESCO Mondialogo Engineering Award, promoting cooperation of student engineers around the world on project proposals for humanitarian engineering. He was also a member of the UN Millennium Project Task Force on Science, Technology and Innovation.

Correspondence concerning this article should be addressed to Tony Marjoram, Manchester Institute of Innovation Research, 25 Red Johanna Road, Johanna, Victoria, Australia. Email: t_marjoram@yahoo.com

\section{Warren Myers}

Dr. Myers is currently Emeritus Professor of Industrial and Management Systems Engineering in the Statler College of Engineering and Mineral Resources. He most recently served as the college Associate Dean for Academic Affairs for 13 years. Prior to serving as the college Associate Dean for Academic Affairs, he served the College as the Chair of the Industrial and Management Systems Engineering Department. Before joining the faculty of WVU, he served 13 years with the U.S. National Institute for Occupational Safety and Health. Dr. Myers is a Certified Industrial Hygienist. He has extensive research and field experience in industrial hygiene specifically with worker exposure assessment to chemical and physical agents, ergonomic and human factors problems, ventilation system assessment and personal protective equipment. Dr. Myers is internationally recognized for his research on respiratory protection and has published over 50 peer-reviewed articles in the scientific literature. He is a three times recipient of the John M. White Award given by the American Industrial Hygiene Association for the best peer reviewed publication on respiratory protection. He is also a recipient of the Edward C. Hyatt Award presented by the International Society for Respiratory Protection for contributions to the arts and science of respiratory protection. Dr. Myers has served on and chaired numerous professional boards and national committees in the area of occupational safety and health.

\section{Jin-hua Wang}

Dr. Jin-hua Wang, born on Feb. 17, 1957 in Gucheng, Hebei, China, supervises Ph.D. students in mining engineering. He is now chairman of China Coal Technology \& Engineering Group (CCTEG), chairman of Tiandi Science and Technology Co., Ltd., and president of China Coal Research Institute. He is also vice president of China National Coal Association, vice chairman of China Coal Society, vice president of the Chinese Society for Rock Mechanics \& Engineering. In addition, he is a member of the Energy Advisory Expert Committee of the National Energy Leading Group. He has involved in more than 40 major research projects including the national $\mathrm{R} \& \mathrm{D}$ program. He has received the first-class and second-class prizes of the National Science and Technology Progress Award. Moreover, he has received 16 prizes of provincial levels. He has published three books and fifty papers.

Correspondence concerning this article should be addressed to Jin-hui Wang, China Coal Technology \& Engineering Group Corp. Email: duxiaojun2011@126.com

\section{Steve Hsueh-Ming Wang}

Steve Hsueh-Ming Wang is an associate professor of Engineering and Science Management Program at University of Alaska. He has an M.S. degree in Manufacturing Engineering from Northwestern University and both an M.S. degree in Management of Technology and a Ph.D. degree in Industrial and Systems Engineering from Lehigh University in the 
USA. Dr. Wang's primary research interests are in sustainability, technology management, cognition engineering, and quality management. He published a book, Six Sigma Project Management. Dr. Wang also has finished more than sixty papers in the disciplinary areas in engineering management, such as, the wind farm design in Anchorage, the feasibility analysis of plasma gasification for waste handling, the smart grid system for solar panel system in the rural area, and the economic analysis of the life cycle of LED street lights. His current research is focusing on the cognitive computing for personality assessment and sustainable design centered systems.

Correspondence concerning this article should be addressed to Steve Hseuh-Ming Wang, College of Engineering, University of Alaska Anchorage, Anchorage, Alaska 99514-1629, USA. Email: hswang@uaa.alaska.edu

\section{David A. Wyrick}

Dr. David A. Wyrick is the Associate Dean for Academic Affairs of the Benjamin M. Statler College of Engineering and Mineral Resources at West Virginia University, USA. He serves as the chief academic officer for 4,000 undergraduate and 700 graduate students. He oversees the recruitment, retention, and academic progress of students, quality of academic programs, and placement of graduating students in industry, government, and academia. WVU enrolls 30,000 students and is ranked at the highest level for a research university in the Carnegie classification system. Dr. Wyrick also serves as the Associate Executive Director of the American Society for Engineering Management. He was the 2011-2012 president and has served in a number of capacities on the ASEM Board of Directors, including Regional Director, Secretary, President-Elect, Immediate Past-President, and Functional Director. He has worked with the Chinese Academy of Engineering's Division of Engineering Management as a liaison for the advancement of the engineering management profession. Prior to moving to West Virginia University in 2015, Dr. Wyrick was Dean of the School of Science and Engineering at Al Akhawayn University in Ifrane, a small public liberal arts and sciences university in the Kingdom of Morocco. Previously, Dr. Wyrick held the Bryan Pearce Bagley Regents Chair of Engineering at Texas Tech University, where he worked in the Whitacre College of Engineering and across the campus to develop technical entrepreneurship and encourage learning abroad. From 1989-2007, Wyrick was at the Department of Mechanical and Industrial Engineering at the University of Minnesota Duluth, rising to Professor and Department Head. Dr. Wyrick worked in the oil and gas industry with projects ranging from exploration, arctic environmental assessment, drilling, production operations, and facilities engineering with Atlantic Richfield Company. He has also worked with IBM-Rochester and many small manufacturing firms on quality, manufacturing, and improvement projects. Dr. Wyrick's research includes effective management of technology in SMEs, engineering education, and engineering management. He has published over 90 journal articles, conference proceedings, book chapters, technical reports, and book reviews. Dr. Wyrick is a member of ASME International, the Institute of Industrial Engineers, and Tau Beta Pi. He has served on the ASME International's Management Division board of directors and as secretary and president of the Alaska Section. He is a licensed professional engineer in the state of Minnesota, USA, and is a certified professional engineering manager.

Correspondence concerning this article should be addressed to David A. Wyrick, American Society for Engineering Management, Huntsville, Alabama 25805, USA. Email: dawyrick@yahoo.com

Or to David A. Wyrick, Statler College of Engineering and Mineral Resources, West Virginia University, Morgantown, West Virginia 26506, USA. Email: david.wyrick@mail.wvu.edu

\section{Li Da Xu}

$\mathrm{Li} \mathrm{Da} \mathrm{Xu}$ is an IEEE Fellow and a foreign member of Russian Academy of Engineering. He serves as the founding chair of IFIP TC8 WG8.9, the founding chair of the IEEE SMC Society Technical Committee on Enterprise Information Systems, and the founding editors-in-chief of the engineering journals entitled Journal of Industrial Information Integration (Elsevier), Journal of Industrial Integration and Management (World Scientific), Journal of Management Analytics (Taylor \& Francis), and Enterprise Information Systems (Taylor \& Francis). He is an endowed Changjiang Chair Professor by the Ministry of Education of China. His affiliations include the Institute of Computing Technology, the Chinese Academy of Sciences, the University of Science and Technology of China, Shanghai Jiao Tong University, the China State Council Development Research Center, and Old Dominion University, USA. He participated in early research and educational academic activities in the subject of systems science and engineering. Professor Xu collaborated and worked extensively with pioneering scholars such as West Churchman, John Warfield, and Xue-sen Qian. Furthermore, 
he spearheaded early research and educational academic activities in the subjects of information systems, enterprise systems as well as industrial information integration, which started in early $1980 \mathrm{~s}$. He is the author of the book entitled Enterprise Integration and Information Architecture-A Systems Perspective on Industrial Information Integration, coauthor of the book entitled Systems Science Methodological Approaches published by Taylor \& Francis Group. His work has been cited by Xue-sen Qian and other well-known scholars.

Correspondence concerning this article should be addressed to Li Da Xu, Old Dominion University, Norfolk, VA 23529, USA. Email: 1xu@odu.edu 